\title{
Six-Year Evaluation of Circular Root Barriers on Two Tree Species
}

\author{
Dennis Pittenger and Donald Hodel
}

\begin{abstract}
The influence of four circular root barriers on surface root development and tree growth was evaluated on Liquidambar styraciflua (American sweetgum) and Ficus microcarpa (Indian laurel fig) in southern California, U.S. Six years after installation, root barriers had reduced the total number of roots growing in the surface $15 \mathrm{~cm}(6 \mathrm{in})$ of soil and nearly eliminated large (diameter $5 \mathrm{~cm}$ [2 in] or greater) surface tree roots within a $120 \mathrm{~cm}$ (48 in) radius of the trunk. Various sizes and types of low-cost noncommercial barriers, including a container-grown tree's nursery container with the bottom removed, were equally effective in reducing the number of large-diameter surface roots. However, roots grew below barriers and returned to the surface soil when soil texture, bulk density, and water content were near optimum for root growth at the bottom of the barrier. Many small roots $1.25 \mathrm{~cm}(0.5 \mathrm{in}) \leq$ diameter less than $2.5 \mathrm{~cm}(0.5 \mathrm{in} \leq$ diameter to less than 1 in) were found growing in the upper $15 \mathrm{~cm}(6$ in) of soil just beyond barriers within 18 to $60 \mathrm{~cm}$ ( 7 to $24 \mathrm{in}$ ) of the trunk. No barrier treatment reduced the number of small roots of either species beyond $60 \mathrm{~cm}$ (24 in) radius from the trunk. Keeping pavement at least $120 \mathrm{~cm}$ (48 in) away from trees would be as effective as a root barrier in reducing the possibility of damage from large surface roots. A \#15 nursery container serving as a root barrier reduced caliper increase of both species, whereas this treatment and the DeepRoot ${ }^{\circledR}$ barrier treatment reduced height increase of Liquidambar.
\end{abstract}

Key Words. Landscape trees; root diameter; root systems; surface roots; tree growth.

When too little urban space is allocated for tree root systems to grow and develop, they often damage nearby infrastructure. In many urban areas of the United States and other countries, tree root damage to infrastructure is a considerable problem (Costello and Jones 2003). For example, McPherson (2000) estimated that in California, U.S. alone, over $\$ 70$ million was spent annually to repair sidewalks, curbs, pavement, and other hardscape broken or lifted by tree roots and that this amount represented only a portion of the repairs that are actually needed.

Installation of circular root barriers when planting street or parking lot trees is often specified as a means of preventing or delaying damage to hardscape by future root growth (Randrup et al. 2001). Research with several tree species has shown root barriers have variable effects on root distribution (Costello and Jones 2003). All of the studies except Gilman (2006) were relatively short-term, evaluating barrier effects approximately 3 years after treatments were established.

An early study by Wilson (1967) under controlled conditions demonstrated that laterally growing, very small 1 to $2 \mathrm{~mm}(0.04$ to 0.08 in) diameter roots of red oak turned downward when presented with a rigid barrier placed perpendicular to their growth path. The roots then grew to the bottom of the barrier, recurved, and continued growing. More recent field research experiments using various physical and chemical barrier treatments with several tree species found roots grew down and under barriers and returned to the soil surface a short distance beyond the barrier (Wagar 1985; Urban 1994; Gilman 1996, 2006; Costello et al. 1997; Peper 1998; Peper and Mori 1999; Smiley 2005; Smiley et al. 2000). Roots that grew down and out of barriers were delayed in reaching the surface soil and occurred there in fewer numbers compared with controls. Sometimes roots were found in the upper $30 \mathrm{~cm}$ (12 in) of soil within $30 \mathrm{~cm}$ (12 in) of the barrier (Costello et al. 1997; Peper 1998; Peper and Mori 1999), whereas other times, they were found in the upper $15 \mathrm{~cm}(6$ in.) of soil at distances from $30 \mathrm{~cm}$ (12 in) to $150 \mathrm{~cm}$ (60 in) from the barrier. The distance outside a barrier that roots would likely return to the surface soil and continue growing was not narrowly defined in these studies. With the exceptions of Gilman (2006) and Smiley (2005), previous studies were conducted with barriers that completely circled the tree root system.

Many studies concluded that tree species and soil properties are the key factors determining the number of roots that return near the soil surface, the depth that they grow, and the distance from the trunk at which they return to the surface (Barker 1995a, 1995b; Costello et al. 1997; Peper 1998; Peper and Mori 1999; Randrup et al. 2001; Gilman 2006).

The objectives of this study were to: 1) compare the effectiveness of three simple, low-cost physical barrier materials and a commercial physical circular root barrier in preventing surface root development of two commonly used landscape tree species several years after planting; 2) determine the influence of these circular physical root barriers on tree growth; and 3) define the distance beyond a barrier that surface roots occur.

\section{MATERIALS AND METHODS}

Two commonly planted street, parking lot, and landscape tree species observed to develop extensive surface roots (Warriner 1999; Costello and Jones 2003), Liquidambar styraciflua L. (American sweetgum) and Ficus microcarpa L.f. (Indian laurel fig), were transplanted from \#5 containers [12.6 l (3.3 gal.)] into a field experiment in June 1992 at the University of California in Riverside, California. Trees were planted at a spacing of $6.1 \mathrm{~m} \times$ $6.1 \mathrm{~m}(20 \mathrm{ft} \times 20 \mathrm{ft})$ in planting pits approximately $1.2 \mathrm{~m} \times 0.9 \mathrm{~m}$ wide $\times 0.8 \mathrm{~m}$ deep $(4 \mathrm{ft} \times 3 \mathrm{ft} \times 2.5 \mathrm{ft})$. The following five circular physical root barrier treatments were established at planting 
(Table 1): 1) control, no barrier; 2) DeepRoot ${ }^{\circledR}$ barrier (model UB 24-2; Deep Root Partners, LP, San Francisco, CA) with dimensions of $0.8 \mathrm{~m}$ ( $2.5 \mathrm{ft}$.) diameter $\times 0.6 \mathrm{~m}$ ( $2 \mathrm{ft})$ deep; 3 ) \#15 plastic nursery container with the bottom removed, having a top diameter $35.6 \mathrm{~cm}$ (14 in), height $43.2 \mathrm{~cm}$ (17 in), and volume 38.61 (10 gal); 4) original \#5 plastic nursery container used to produce the tree with the bottom removed and having a top diameter $25.4 \mathrm{~cm}$, height $30.5 \mathrm{~cm}$, and volume 12.6 l (3.3 gal); and 5) black polyethylene, $0.3 \mathrm{~mm}(0.012 \mathrm{in})$ thick, formed into a sleeve the same dimensions as the \#15 container. The sleeve was manufactured on-site by wrapping the polyethylene from a roll around a \#15 container and applying vinyl adhesive tape to hold the seam.

The study was a $2 \times 5$ factor (two tree species $\times$ five root barrier treatments) experiment with 10 replicates arranged in a fully randomized $10 \times 10$ Latin square design of 100 trees. Tree growth, root size, and root location data were subjected to analysis of variance using the GLM procedure in SAS (SAS Institute, Inc., Cary, NC).

Planting pits were partially filled with soil and watered to settle the soil before setting the barriers. Backfill consisted of the native soil excavated from the planting pits. Barriers were set so that their top edge was $5 \mathrm{~cm}$ ( 2 in) above the surrounding grade, and trees were transplanted into barriers so that the surface of their root balls was even with the surrounding grade. Control trees and trees retained in their \#5 plastic nursery container with the bottom removed were planted so that their root balls were even with the surrounding soil. Trees were not staked because their trunks were of sufficient caliper to support them. The entire plot was thoroughly irrigated before transplanting and trees were thoroughly hand-watered immediately after final backfilling of the planting pits and barriers.

The soil at the site was a Hanford coarse sandy loam (coarseloamy, mixed, thermic Typic Durizeralf) with $\mathrm{pH}$ of 7.2, electrical conductivity $1.0 \mathrm{dS} / \mathrm{m}^{-1}$, and bulk density of 1.4 to $1.5 \mathrm{~g} / \mathrm{cm}^{-3}$. Its characteristics were uniform to a depth of at least $60 \mathrm{~cm}$. The entire field was deep tilled before planting which reduced the bulk density to $1.2 \mathrm{~g} / \mathrm{cm}^{-3}$. At the end of the study, the bulk density was remeasured and averaged $1.5 \mathrm{~g} / \mathrm{cm}^{-3}$ or less to a depth of $60 \mathrm{~cm}$.

Irrigation was managed during the study so that soil water content was not limiting below the bottom of the root barriers. Soil water content was monitored by gravimetric soil moisture determinations and a pair of tensiometers placed approximately $15 \mathrm{~cm}$ outside the barrier at one replicate of each barrier-tree species treatment. One tensiometer was set $30 \mathrm{~cm}$ and one 60 $\mathrm{cm}$ deep at each location. Irrigation was scheduled to maintain soil moisture content at $70 \%$ or greater of field capacity at the $60 \mathrm{~cm}$ depth, which assured nonlimiting soil moisture for root development below the deepest root barrier treatment. As a result of the Mediterranean climate in Riverside, irrigation was scheduled regularly and frequently (two to four times per week) from spring through fall and irregularly and infrequently during the

Table 1. Dimensions and interior surface features of circular root barrier treatments, Riverside, CA.

\begin{tabular}{|c|c|c|c|c|}
\hline Barrier & $\mathrm{Ht}(\mathrm{cm})$ & $\begin{array}{l}\text { Diameter of } \\
\text { top }(\mathrm{cm})\end{array}$ & Volume (L) & Interior surface \\
\hline \#5 container & 30.5 & 25.4 & 12.6 & Smooth \\
\hline Polyethylene sleeve & 43.2 & 35.6 & 38.6 & Smooth \\
\hline \#15 container & 43.2 & 35.6 & 38.6 & Smooth \\
\hline DeepRoot $^{\circledR}$ UB 24-2 & 61.0 & 61.0 & 163.4 & Vertical ribs \\
\hline
\end{tabular}

winter. The planting was irrigated for the first 11 months with drip irrigation in which an emitter was placed inside and immediately outside of each barrier to maintain the desired level of soil moisture in and below the barrier. From Month 12 to the end of the experiment, the planting was irrigated with a minisprinkler system that applied water to the entire planted area. Trees were fertilized annually in the spring or early summer the first 3 years of the study, and no fertilizer was applied in succeeding years. In Years 1 and 2, each tree received $37 \mathrm{~g}(1.3 \mathrm{oz})$ nitrogen $(\mathrm{N})$ from urea applied within the dripline; in Year 3, each tree received $71 \mathrm{~g}$ (2.5 oz) $\mathrm{N}$ from 21-0-0 applied also applied within the dripline.

The field was kept weed-free in Years 1 through 3 by the combination of hand-weeding and pre-emergent herbicides (oxadiazon $2 \%$ and oryzalin $4 \mathrm{AS}$ at minimum label rates) applied each spring and fall. Weed management was achieved in succeeding years with hand-weeding and spot-spray applications of glyphosate.

Tree height and trunk caliper $15 \mathrm{~cm}$ above the soil line were measured annually. Six years after planting, trees were cut $60 \mathrm{~cm}$ above the soil, their canopies discarded, and the root zone of each tree was excavated using the tines on the bucket of a backhoe in combination with hand-raking to remove the upper $15 \mathrm{~cm}$ of soil in a radius of $180 \mathrm{~cm}$ (72 in) from the trunk. Excavation with the backhoe bucket tines began at the outer edge of a barrier (at the bases of the trunk in control trees), and soil was progressively loosened away from the trunk to a radius of $180 \mathrm{~cm}$. The backhoe portion of the procedure was monitored directly by the authors and involved tedious, careful, and methodic use of the tines to loosen the upper 8 to $10 \mathrm{~cm}$ of soil and tease out the roots of each tree that were $1.25 \mathrm{~cm}(0.5 \mathrm{in})$ or greater in diameter. Hand-raking immediately followed the backhoe operation to remove the remaining soil to a final depth of $15 \mathrm{~cm}$ and to clearly expose the principal root system found within the excavated area. Caution was taken during excavation to avoid breaking off roots $1.25 \mathrm{~cm}$ or greater in diameter. In the rare instances when a root was broken off, the location it was growing in was marked so that it could be replaced and recorded during data collection.

The excavated area was divided into five concentric radial distance zones from the center of the trunk as described in Table 2. These zones enabled us to compare the barriers' effectiveness in reducing surface root development and to narrowly delineate

\section{Table 2. The five concentric radial distance zones from the center of each tree trunk in which roots to a depth of $15 \mathrm{~cm}$ were quantified in a root barrier study, Riverside, CA.}

\begin{tabular}{|c|c|c|}
\hline Zone & Distance from trunk & Distance represented \\
\hline 1 & $\begin{array}{r}13 \mathrm{~cm}<\text { radius } \leq 18 \mathrm{~cm} \\
(5 \mathrm{in}<\text { radius } \leq 7 \mathrm{in})\end{array}$ & $\begin{array}{l}\text { From the perimeter of the } \# 5 \text { container } \\
\text { barrier out to the perimeter of the } \\
\# 15 \text { container and polyethylene } \\
\text { barriers }\end{array}$ \\
\hline 2 & $\begin{array}{l}18 \mathrm{~cm}<\text { radius } \leq 30 \mathrm{~cm} \\
\quad(7 \mathrm{in}<\text { radius } \leq 12 \mathrm{in})\end{array}$ & $\begin{array}{l}\text { From the perimeter of the } \# 15 \\
\text { container and polyethylene } \\
\text { barriers out to the perimeter of the } \\
\text { DeepRoot barrier }\end{array}$ \\
\hline 3 & $\begin{array}{l}30 \mathrm{~cm}<\text { radius } \leq 60 \mathrm{~cm} \\
\quad(12 \mathrm{in}<\text { radius } \leq 24 \mathrm{in})\end{array}$ & $\begin{array}{l}\text { From the perimeter of the DeepRoot } \\
\text { barrier out to } 30 \mathrm{~cm} \text { beyond the } \\
\text { barrier }\end{array}$ \\
\hline 4 & $\begin{aligned} 60 \mathrm{~cm} & <\text { radius } \leq 120 \mathrm{~cm} \\
& (24 \mathrm{in}<\text { radius } \leq 48 \mathrm{in})\end{aligned}$ & From $60 \mathrm{~cm}$ to $120 \mathrm{~cm}$ from trunk \\
\hline 5 & $\begin{array}{r}120 \mathrm{~cm}<\text { radius } \leq 180 \mathrm{~cm} \\
(48 \mathrm{in}<\text { radius } \leq 72 \mathrm{in})\end{array}$ & From $120 \mathrm{~cm}$ to 180 from trunk \\
\hline
\end{tabular}


Table 3. Effects of five root barrier treatments on mean number of roots $1.25 \mathrm{~cm}(0.5 \mathrm{in})$ or greater diameter for two tree species averaged over five radial distance zones from the trunk 6 years after planting, Riverside, CA, 1998.

\begin{tabular}{ll}
\hline Barrier & Mean no. of roots \\
\hline Check & $4.3 \mathrm{a}$ \\
Polyethylene sleeve & $2.3 \mathrm{~b}$ \\
\#5 container & $2.2 \mathrm{~b}$ \\
DeepRoot & $1.1 \mathrm{c}$ \\
$\# 15$ container $^{\circledR}$ & $1.0 \mathrm{c}$ \\
\hline
\end{tabular}

Species

\begin{tabular}{ll}
\hline Liquidambar & $2.6 \mathrm{a}$ \\
Ficus & $1.9 \mathrm{~b}$ \\
Least significant difference $(P=0.05)$ & 0.5
\end{tabular}

Statistical effects ${ }^{\mathrm{z}}$

Species (S)

Barrier (B)

$*$

$\mathrm{S} \times \mathrm{B}$

NS

${ }^{2} \mathrm{NS}, *, * *, * * *=$ not significant and significant at $P \leq 0.05,0.01$, and 0.001 , respectively. Means followed by the same letter are not significantly different.

the distance beyond each barrier treatment that surface roots appeared and grew. Roots with diameter $1.25 \mathrm{~cm}$ or greater were counted in each distance zone they grew in within the surface $15 \mathrm{~cm}$ of soil. In each zone, counted roots included those emerging from deeper than $15 \mathrm{~cm}$ in the soil within the zone as well as those growing into the zone after emerging into the surface $15 \mathrm{~cm}$ of soil in a different zone. Roots were classified into the following diameter size classes: 1) small, $1.25 \mathrm{~cm} \leq$ diameter to less than $2.5 \mathrm{~cm}$ (0.5 in $\leq$ diameter to less than $1 \mathrm{in}) ; 2$ ) medium, $2.5 \mathrm{~cm} \leq$ diameter to less than $5 \mathrm{~cm}(1 \mathrm{in} \leq$ diameter $<2$ in); and 3) large, diameter $5 \mathrm{~cm}$ or greater (2 in or greater).

\section{RESULTS}

\section{Surface Root Development}

Overall, barrier treatments reduced the total number of roots $1.25 \mathrm{~cm}$ or greater in diameter growing in the excavated area for both species with the DeepRoot and \#15 container barriers allowing the fewest (Table 3). Liquidambar developed more measurable roots than Ficus in the excavated area regardless of barrier treatment, and root systems of Liquidambar appeared more branched than those of Ficus. Reduced numbers of small roots were unearthed in the surface $15 \mathrm{~cm}$ of soil a short distance outside of each barrier treatment in both species (Tables 4 and 5). Thus, small roots were found within Zone 1 in \#5 container barriers, Zone 2 in the \#15 container and polyethylene sleeve barriers, and Zone $3 \mathrm{~cm}$ in the DeepRoot barrier. In both species, control and barrier-treated trees had produced few medium or large roots beyond a $120 \mathrm{~cm}$ radius (Zone 4) from the trunk.

In Ficus, barrier treatments equally reduced small-diameter roots to a radius of $60 \mathrm{~cm}$ (Zones 1 to 3 ) from the trunk and medium- and large-diameter roots to a radius of $120 \mathrm{~cm}$ (Zones 1 to 4) from the trunk (Table 4). Occasionally, Ficus roots breached the \#5 container or polyethylene sleeve barriers. In Liquidambar, the \#15 container and DeepRoot treatments equally reduced small-diameter roots to a radius of $60 \mathrm{~cm}$ from the trunk, but the $\# 5$ container and polyethylene sleeve treatments failed to reduce small roots within this radius (Table 5). Barrier treatments were equally effective in eliminating large Liquidambar roots to a radius of $60 \mathrm{~cm}$ from the trunk, and all barriers except the polyethylene sleeve reduced medium-diameter roots to a radius of $180 \mathrm{~cm}$ (Zones 1 to 5) from the trunk. Liquidambar roots of all size classes were often found growing out through breaches in the sides of the \#5 container and polyethylene sleeve barriers.

Trunks of both species grew large enough in caliper during the 6-year study period for their bases to fill and frequently split the \#5 container barriers, whereas the taped seams of the polyethylene sleeve barriers repeatedly failed. Also, the exposed rim of the polyethylene sleeve degraded with time and occasional small roots of both species were observed growing over this barrier. Because Liquidambar generally produced more roots of all sizes and more roots closer to the trunk than Ficus, the structural failures of these two barrier treatments made them ineffective at reducing small- and medium-sized roots of Liquidambar.

\section{Tree Growth}

Cumulative increase in trunk caliper of both species 6 years after planting was reduced only by the \#15 container barrier, and Ficus had greater cumulative increase in trunk caliper than Liquidambar (Table 6). There was an interaction between tree species and barriers on cumulative height increase (Table 7). Ficus height growth was unaffected by barrier treatment, but height increase of Liquidambar was reduced in the DeepRoot and \#15 container

Table 4. Effects of root barriers on mean numbers of small, medium, and large roots of Ficus microcarpa present within $15 \mathrm{~cm}$ ( 6 in) of the soil surface in five radial distance zones from the trunk 6 years after planting, Riverside, CA, 1998. ${ }^{2}$

\begin{tabular}{|c|c|c|c|c|c|c|c|c|c|c|c|c|c|c|c|}
\hline \multirow[b]{2}{*}{ Barrier } & \multicolumn{3}{|c|}{$\begin{array}{c}\text { Zone } 1(3 \mathrm{~cm}<\text { radius } \\
\leq 18 \mathrm{~cm})\end{array}$} & \multicolumn{3}{|c|}{$\begin{array}{c}\text { Zone } 2(18 \mathrm{~cm}<\text { radius } \\
\leq 30 \mathrm{~cm})\end{array}$} & \multicolumn{3}{|c|}{$\begin{array}{c}\text { Zone } 3(30 \mathrm{~cm}<\text { radius } \\
\leq 60 \mathrm{~cm})\end{array}$} & \multicolumn{3}{|c|}{$\begin{array}{c}\text { Zone } 4(60 \mathrm{~cm}<\text { radius } \\
\leq 120 \mathrm{~cm})\end{array}$} & \multicolumn{3}{|c|}{$\begin{array}{c}\text { Zone } 5(120 \mathrm{~cm}<\text { radius } \\
\leq 180 \mathrm{~cm})\end{array}$} \\
\hline & Small & Medium & Large & Small & Medium & Large & Small & Medium & Large & Small & Medium & Large & Small & Medium & Large \\
\hline Check & $1.6 \mathrm{a}$ & $2.9 \mathrm{a}$ & $4.2 \mathrm{a}$ & $2.9 \mathrm{a}$ & $3.1 \mathrm{a}$ & $3.6 \mathrm{a}$ & $5.3 \mathrm{a}$ & $3.7 \mathrm{a}$ & $2.5 \mathrm{a}$ & 9.5 & $5.2 \mathrm{a}$ & 1.0 & 6.8 & 2.4 & 0.1 \\
\hline \#5 container & $0.6 \mathrm{~b}$ & $0.3 \mathrm{~b}$ & $0.6 \mathrm{~b}$ & $1.3 \mathrm{~b}$ & $0.5 \mathrm{~b}$ & $0.6 \mathrm{bc}$ & $2.1 \mathrm{~b}$ & $1.9 \mathrm{~b}$ & $0.5 \mathrm{~b}$ & 8.2 & $1.9 \mathrm{~b}$ & $0.0 \mathrm{~b}$ & 5.6 & 0.7 & 0.0 \\
\hline Polyethylene sleeve & - & - & - & $0.7 \mathrm{~b}$ & $0.9 \mathrm{~b}$ & $0.9 \mathrm{c}$ & $2.4 \mathrm{~b}$ & $1.9 \mathrm{~b}$ & $1.0 \mathrm{~b}$ & 5.7 & $2.8 \mathrm{~b}$ & $0.6 \mathrm{ab}$ & 6.7 & 2.5 & 0.1 \\
\hline \#15 container & - & - & - & $0.4 \mathrm{~b}$ & $0.2 \mathrm{~b}$ & $0.0 \mathrm{c}$ & $2.3 \mathrm{~b}$ & $0.6 \mathrm{c}$ & $0.2 \mathrm{~b}$ & 5.4 & $1.1 \mathrm{~b}$ & $0.2 \mathrm{~b}$ & 5.4 & 1.2 & 0.0 \\
\hline DeepRoot $^{\circledR}$ & - & - & - & - & - & - & $1.5 \mathrm{~b}$ & $0.8 \mathrm{bc}$ & $0.1 \mathrm{~b}$ & 6.5 & $1.7 \mathrm{~b}$ & $0.0 \mathrm{~b}$ & 7.1 & 1.4 & 0.0 \\
\hline Least significant & 0.8 & 0.9 & 0.8 & 1.4 & 1.2 & 0.8 & 1.9 & 1.2 & 1.0 & NS & 1.9 & 0.6 & NS & NS & NS \\
\hline
\end{tabular}

differencey $^{y}(P=0.05)$

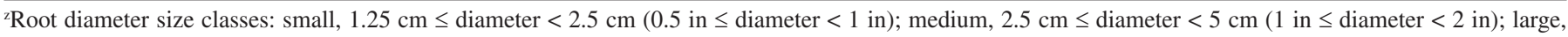
diameter $\leq 5 \mathrm{~cm}$ (diameter $\leq 2$ in).

${ }^{y} \mathrm{NS}=$ not significant; means within columns followed by the same letter are not significantly different. 
Table 5. Effects of root barriers on mean numbers of small, medium, and large roots of Liquidambar styraciflua present within $15 \mathrm{~cm}$ ( 6 in) of the soil surface in five radial distance zones from the trunk 6 years after planting, Riverside, CA, 1998. ${ }^{2}$

\begin{tabular}{|c|c|c|c|c|c|c|c|c|c|c|c|c|c|c|c|}
\hline \multirow[b]{2}{*}{ Barrier } & \multicolumn{3}{|c|}{$\begin{array}{c}\text { Zone } 1(3 \mathrm{~cm}<\text { radius } \\
\leq 18 \mathrm{~cm})\end{array}$} & \multicolumn{3}{|c|}{$\begin{aligned} & \text { Zone } 2(18 \mathrm{~cm}<\text { radius } \\
&\leq 30 \mathrm{~cm})\end{aligned}$} & \multicolumn{3}{|c|}{$\begin{array}{c}\text { Zone } 3(30 \mathrm{~cm}<\text { radius } \\
\leq 60 \mathrm{~cm})\end{array}$} & \multicolumn{3}{|c|}{$\begin{array}{c}\text { Zone } 4(60 \mathrm{~cm}<\text { radius } \\
\leq 120 \mathrm{~cm})\end{array}$} & \multicolumn{3}{|c|}{$\begin{array}{c}\text { Zone } 5(120 \mathrm{~cm}<\text { radius } \\
\leq 180 \mathrm{~cm})\end{array}$} \\
\hline & Small & Medium & Large & Small & Medium & Large & Small & Medium & Large & Small & Medium & Large & Small & Medium & Large \\
\hline Check & $3.7 \mathrm{a}$ & $3.1 \mathrm{a}$ & $4.0 \mathrm{a}$ & $7.0 \mathrm{a}$ & $4.6 \mathrm{a}$ & $4.2 \mathrm{a}$ & $11.9 \mathrm{a}$ & $6.6 \mathrm{a}$ & $2.3 \mathrm{a}$ & 14.6 & $4.8 \mathrm{a}$ & 0.4 & 6.3 & $1.7 \mathrm{a}$ & 0.1 \\
\hline \#5 container & $4.0 \mathrm{a}$ & $1.4 \mathrm{~b}$ & $0.3 \mathrm{~b}$ & $6.8 \mathrm{a}$ & $1.6 \mathrm{bc}$ & $0.0 \mathrm{~b}$ & $9.0 \mathrm{a}$ & $2.2 \mathrm{bc}$ & $0.1 \mathrm{~b}$ & 8.4 & $0.7 \mathrm{~b}$ & 0.0 & 5.3 & $0.4 \mathrm{~b}$ & 0.0 \\
\hline Polyethylene sleeve & - & - & - & $3.9 \mathrm{ab}$ & $2.0 \mathrm{~b}$ & $0.5 \mathrm{~b}$ & $9.4 \mathrm{a}$ & $3.8 \mathrm{ab}$ & $0.8 \mathrm{~b}$ & 12.9 & $2.7 \mathrm{ab}$ & 0.2 & 6.4 & $0.5 \mathrm{~b}$ & 0.0 \\
\hline \#15 container & - & - & - & $1.5 \mathrm{bc}$ & $0.0 \mathrm{c}$ & $0.0 \mathrm{~b}$ & $3.1 \mathrm{~b}$ & $0.1 \mathrm{c}$ & $0.0 \mathrm{~b}$ & 5.4 & $0.5 \mathrm{~b}$ & 0.0 & 2.5 & $0.1 \mathrm{~b}$ & 0.0 \\
\hline DeepRoot $^{\circledR}$ & - & - & - & - & - & - & $2.1 \mathrm{~b}$ & $0.6 \mathrm{c}$ & $0.0 \mathrm{~b}$ & 7.0 & $0.4 \mathrm{~b}$ & 0.0 & 4.2 & $0.1 \mathrm{~b}$ & 0.0 \\
\hline $\begin{array}{l}\text { Least significant } \\
\quad \text { difference }^{y}(P=0.05)\end{array}$ & 2.0 & 1.5 & 0.9 & 3.8 & 1.8 & 1.2 & 4.3 & 3.0 & 1.2 & NS & 3.2 & NS & NS & 1.1 & NS \\
\hline
\end{tabular}

${ }^{2}$ Root diameter size classes: small, $1.25 \mathrm{~cm} \leq$ diameter $<2.5 \mathrm{~cm}(0.5 \mathrm{in} \leq$ diameter $<1 \mathrm{in})$; medium, $2.5 \mathrm{~cm} \leq$ diameter $<5 \mathrm{~cm}(1 \mathrm{in} \leq$ diameter $<2 \mathrm{in})$; large, diameter $\leq 5 \mathrm{~cm}$ (diameter $\leq 2 \mathrm{in})$.

${ }^{y} \mathrm{NS}=$ not significant; means within columns followed by the same letter are not significantly different.

barriers, with the \#15 container treatment having the most dramatic height reduction. Trees growing in the \#15 container and DeepRoot barrier treatments also produced the fewest total roots in the excavated area, which may be in part responsible for the reduced growth exhibited by trees in these barriers. Trees whose growth was reduced did not express diminution in any other aesthetic characteristics.

\section{DISCUSSION}

Our findings provide confirmation of similar results from the shorter-term studies reviewed here, document the size of larger roots that develop near the surface 6 years after planting, and narrowly delineate the distance outside a barrier where surface roots will likely appear several years after installation. The results demonstrate circular physical root barriers of various dimensions and formed from of a variety of low-cost materials are about as effective as commercial root barriers and can nearly eliminate large surface tree roots to a $180 \mathrm{~cm}$ radius of the trunk for at

Table 6. Mean cumulative trunk caliper increase in Liquidambar styraciflua and Ficus microcarpa 6 years after planting in five circular root barrier treatments, Riverside, CA, 1998.

\begin{tabular}{lc}
\hline Barrier treatment & $\mathrm{mm}$ \\
\hline Check & $160.0 \mathrm{a}$ \\
12 mil polyethylene & $156.0 \mathrm{ab}$ \\
5 gallon & $161.8 \mathrm{a}$ \\
DeepRoot & $159.7 \mathrm{a}$ \\
15 gallon $^{\circledR}$ & $143.9 \mathrm{~b}$ \\
Least significant difference $(P=0.05)$ & 12.6 \\
\hline Species treatment & \\
\hline Liquidambar & $149.1 \mathrm{a}$ \\
Ficus & $162.8 \mathrm{~b}$ \\
Least significant difference $(P=0.05)$ & 8.0 \\
\hline $2 \times 5$ factorial statistical effects ${ }^{2}$ & $* *$ \\
\hline Species $(\mathrm{S})$ & NS \\
Barrier $(\mathrm{B})$ & \\
$\mathrm{S} \times \mathrm{B}$ & \\
${ }^{2} \mathrm{NS}, *, * *, * * *$ \\
0.001, not significant, and significant at $P=0.05,0.01$, and \\
different.
\end{tabular}

least 6 years after trees are planted. For container-grown trees, simply removing the bottom of a tree's nursery container and planting it directly in the landscape can effectively reduce the number of large surface roots that develop. Our findings agree with Costello et al. (1997) in that trees produce fewer surface roots 120 to $180 \mathrm{~cm}$ from the trunk. Thus, simply keeping pavement and other hardscape at least $120 \mathrm{~cm}$ away from trees might be equally effective as a root barrier in reducing the possibility of surface root problems.

However, 6 years after barriers and trees were installed, smaller roots had returned in reduced numbers to the surface soil just beyond the barriers, and we found many roots $1.25 \mathrm{~cm}$ or greater in diameter less than $2.5 \mathrm{~cm}$ growing in the upper $15 \mathrm{~cm}$ of the soil just beyond barriers and within 18 to $60 \mathrm{~cm}$ of the tree trunk. No barrier treatment reduced the number of small roots (those greater than 1.25 and less than $2.5 \mathrm{~cm}$ in diameter in this study) of either species beyond $60 \mathrm{~cm}$ radius from the trunk. It is reasonable that in many sites, roots in this diameter class would continue growing in diameter and could potentially cause damage to overlaying or adjacent pavement and infrastructure in the future. The results underscore conclusions of Costello et al. (1997) that root barriers only delay problems from surface roots and of Gilman (1996) that reduced root numbers do not necessarily mean less root damage.

\section{Table 7. Mean cumulative height increase in Liquidambar styraciflua and Ficus microcarpa 6 years after planting in five circular root barrier treatments, Riverside, CA, 1998.}

\begin{tabular}{|c|c|c|}
\hline Barrier treatment & Ficus $(\mathrm{cm})$ & Liquidambar $(\mathrm{cm})$ \\
\hline Check & 379.6 & $496.4 \mathrm{a}$ \\
\hline 12 mil polyethylene & 396.5 & $437.6 \mathrm{a}$ \\
\hline 5 gallon & 445.3 & $451.8 \mathrm{ab}$ \\
\hline DeepRoot $^{\circledR}$ & 455.4 & $402.9 \mathrm{~b}$ \\
\hline 15 gallon & 393.2 & $329.0 \mathrm{~b}$ \\
\hline Least significant difference $(P=0.05)$ & NS & 75.1 \\
\hline \multicolumn{3}{|l|}{$2 \times 5$ factorial statistical effects ${ }^{2}$} \\
\hline Species (S) & & NS \\
\hline Barrier (B) & & $* *$ \\
\hline $\mathrm{S} \times \mathrm{B}$ & & $* * *$ \\
\hline
\end{tabular}


The depth of the barrier and its interior surface configuration (smooth or vertical ribs) are less important than its diameter, because the \#5 container barrier failed because it was too small in diameter, whereas the \#15 container and DeepRoot barriers performed equally well even though the \#15 container was $18 \mathrm{~cm}$ ( 7 in) shorter and smooth inside. Although the \#5 container barrier reduced the number of surface roots that developed during the term of our study, our results also indicate that root barriers should be constructed of durable material and installed with the top edge exposed, similar to conclusions of Peper and Barker (1993). Also, they must be large enough in diameter [36 cm (14 in) minimum] to accommodate the roots and root crowns of mature trees to maximize the effect on surface root development.

Although others concluded that root barriers may be most effective at reducing surface root development in sites with well-drained, noncompacted soil(Wagar 1985; Urban 1994; Barker 1995a, 1995b; Gilman 1996), we found that tree roots grew below a barrier and returned to the surface soil a very short distance beyond the barriers even when soil texture, bulk density, and water content were near optimum for root growth at the bottom of the barrier. The uniform coarse sandy loam soil in our experimental plot was maintained at well-watered conditions with irrigation throughout the study, and its bulk density from the surface to the depth of the barrier was $1.5 \mathrm{~g} / \mathrm{cm}^{-3}$ or less, which is not limiting to root growth in sandy loam soil (Veihmeyer and Hendrickson 1948; Zisa et al. 1980). These findings are supported by Gilman (2006) in which barriers in well-drained soil did not produce deeper root systems.

The tree growth results establish that circular root barriers can reduce growth in some tree species, although the reductions documented in the study were not viewed to be enough to reduce the trees' aesthetic value. Data from the study also provide documentation of surface root system distribution for Ficus and Liquidambar.

\section{LITERATURE CITED}

Barker, P.A. 1995a. Managed development of tree roots I. Ultra-deep root ball and root ball casing effects on European hackberry. Journal of Arboriculture 21:202-208.

_ 1995b. Managed development of tree roots II. Ultra-deep root ball and root ball casing effects on southwestern black cherry. Journal of Arboriculture 21:251-259.

Costello, L.R., C.L. Elmore, and S. Steinmaus. 1997. Tree response to circling root barriers. Journal of Arboriculture 23:211-218.

Costello, L.R., and K.S. Jones. 2003. Reducing Infrastructure Damage by Tree Roots: A. Compendium of Strategies. Western Chapter of the International Society of Arboriculture, Cohasset, CA.

Gilman, E.F. 1996. Root barriers affect root distribution. Journal of Arboriculture 22:151-154.

. 2006. Deflecting roots near sidewalks. Arboriculture and Urban Forestry 32:18-23.

McPherson, E.G. 2000. Expenditures associated with conflicts between street tree root growth and hardscape in California, United States. Journal of Arboriculture 26:289-297.

Peper, P.J. 1998. Comparison of root barriers installed at two depths for reduction of white mulberry roots in the soil surface, pp. 82-93. In: Neely, D., and G.W. Watson (Eds.). The Landscape Below Ground II: Proceedings of an International Workshop on Tree Root Development in Urban Soils, 5-8 March 1998, San Francisco, CA. International Society of Arboriculture, Champagne, IL.

Peper, P.J., and P.A. Barker. 1993. A buyer's technical guide to root barriers, pp.186-193. In: Watson, G.W., and D. Neely (Eds.). The Landscape
Below Ground: Proceedings of an International Workshop on Tree Root Development in Urban Soils, 1 Sept. and 1 Oct. 1993, Lisle, IL. International Society of Arboriculture, Savoy, IL.

Peper, P.J., and S. Mori. 1999. Root barriers and extension casing effects on Chinese hackberry. Journal of Arboriculture 25:1-8.

Randrup, T.B., E.G. McPherson, and L.R. Costello. 2001. A review of tree root conflicts with sidewalks, curbs, and roads. Urban Ecosystems 5:209-225.

Smiley, E. T., A. Key, and C. Greco. 2000. Root barriers and windthrow potential. Journal of Arboriculture 26:213-217.

Smiley, E.T. 2005. Root growth near vertical root barriers. Journal of Arboriculture 31:150-152.

Urban, J. 1994. Root barriers: An evaluation. Landscape Architecture 84:28-30.

Veihmeyer, F.J., and A.H. Hendrickson. 1948. Soil density and root penetration. Soil Science 65:487-493.

Wagar, J.A. 1985. Reducing surface rooting of trees with control planters and wells. Journal of Arboriculture 11:165-171.

Warriner, W. 1999. The Ficus tree. Western Arborist 24:48-50.

Wilson, B.F. 1967. Root growth around barriers. Botanical Gazette 128:79-82.

Zisa, R.P., H.G. Halverson, and B.J. Stout. 1980. Establishment and early growth of urban conifers on compact soils. USDA Forest Service Research Paper NE-451.

Dennis Pittenger (corresponding author)
University of California Cooperative Extension,
Central Coast \& South Region
Department of Botany \& Plant Sciences
University of California, Riverside
4114 Batchelor Hall
Riverside, CA 92521 , U.S.
Dennis.pittenger@ucr.edu
Donald Hodel
University of California Cooperative Extension,
Los Angeles County
P. O. Box 22255
Los Angeles, CA 90022

Résumé. L'influence de quatre barrière racinaires circulaires sur le développement des racines de surface et sur la croissance de l'arbre a été évalué sur le Liquidambar styraciflua et le Ficus macrocarpa dans le Sud de la Californie. Six ans après leur installation, les barrières racinaires ont réduit le nombre total de racines poussant dans les 15 premiers centimètres de sol et ont pratiquement éliminé les grosses racines de surface $(5 \mathrm{~cm}$ et plus de diamètre) dans un rayon de $120 \mathrm{~cm}$ autour du tronc. Divers types et dimensions de barrières non commerciales à faibles coûts - incluant les pots servant à la production des arbres en pépinière dont on avait enlevé le fond - se sont aussi avérés efficaces pour diminuer le nombre de grosses racines de surface. Cependant, les racines ont poussé sous les barrières et sont par la suite revenu à la surface, et ce même si la texture du sol, sa densité et son contenu en eau étaient à peu près à un degré optimum pour la croissance des racines sous le niveau de la barrière. Plusieurs petites racines de 1,25 à $2,5 \mathrm{~cm}$ de diamètre ont été observées qui poussaient dans les 15 premiers centimètres de sol juste au-delà de la barrière soit à 18 à $60 \mathrm{~cm}$ de distance du tronc. Aucun type de barrière ne parvient à réduire le nombre de petites racines de chacune de ces deux espèces au-delà d'un rayon de $60 \mathrm{~cm}$ du tronc. Maintenir les surfaces pavées à une distance minimale de $120 \mathrm{~cm}$ de l'arbre devrait être aussi 
efficace qu' une barrière racinaire pour diminuer les risques de dommages par les grosses racines de surface. Le pot de production en pépinière de calibre \#15 qui a servi de barrière racinaire a causé une diminution de la croissance en diamètre du tronc chez les deux espèces tandis que cette méthode ainsi que la barrière DeepRoot ${ }^{\circledR}$ ont causé une diminution de la croissance en hauteur chez le Liquidambar.

Zusammenfassung. In dieser Studie wird der Einfluss von 4 Wurzelbarrieren auf die Wurzelentwicklung und das Baumwachstum bei Amberbaum und Lorbeerfeige in Südkalifornien bewertet. 6 Jahre nach der Installation hatten die Wurzelbarrieren die Gesamtzahl der Wurzeln, die in die oberflächigen ersten $15 \mathrm{~cm}$ Boden wuchsen, reduziert und nahezu alle größeren ( $5 \mathrm{~cm}$ und größer) Wurzeln bis $120 \mathrm{~cm}$ Radius vom Stamm eliminiert. Verschiedene Größen und Typen von billigen, nicht-kommerziellen Wurzelbarrieren einschließlich von bodenlosen Pflanzcontainern waren ebenso effektiv bei der Reduzierung von größeren Wurzeln. Dennoch wuchsen auch Wurzeln unter den Barrieren durch wieder an die Oberfläche, obwohl die Bodenbedingungen im Oberboden suboptimal und am Boden der Wurzelbarrieren optimal waren. Viele kleine Wurzeln mit einem Durchmesser von $1,25 \mathrm{~cm}$, weniger als $2,5 \mathrm{~cm}$, wurden in den oberen $15 \mathrm{~cm}$ Boden gerade außerhalb der Barrieren innerhalb von 18 bis $60 \mathrm{~cm}$ Entfernung vom Stamm gefunden. Keine Barriere konnte die Anzahl der kleinen Wurzeln jenseits des Abstands von $60 \mathrm{~cm}$ zum Stamm reduzieren. Ein Abstand des Pflasters von $120 \mathrm{~cm}$ zum Stamm würde genauso effektiv sein wie eine Wurzelbarriere bei der Reduzierung von Schaden durch große, oberflächennah wachsenden Wurzeln. Ein \# 15 Pflanzcontainer reduzierte bei beiden Arten den Umfang, und ein
Pflanzcontainer kombiniert mit einer Wurzelbarriere reduzierte das Höhenwachstum von Amberbäumen.

Resumen. Se evaluó la influencia de cuatro barreras circulares para el desarrollo de raíces superficiales y el crecimiento de árboles de Liquidambar styraciflua (American sweetgum) y Ficus microcarpa (Laurel de la India) en el sur de California, U.S. Seis años después de la instalación, las barreras de raíces habían reducido el número total de raíces creciendo en los 15 $\mathrm{cm}$ superficiales de suelo y casi eliminaron las grandes raíces superficiales (diámetros de $5 \mathrm{~cm}$ o mayores) dentro de un radio de $120 \mathrm{~cm}$ (48 pulg) del tronco. Varios tipos y tamaños de barreras no comerciales de bajo costo, incluyendo un contenedor de vivero con el fondo removido, fueron igualmente efectivos en reducir el número de raíces superficiales de gran diámetro. Sin embargo, las raíces crecieron debajo de las barreras y regresaron a la superficie del suelo, aún cuando la textura del suelo, la densidad y el contenido de humedad fueron cerca del óptimo para el crecimiento de las raíces en el fondo de la barrera. Muchas raíces pequeñas $(\leq 2.5 \mathrm{~cm})$ fueron encontradas en los $15 \mathrm{~cm}$ superiores de suelo, más allá de las barreras dentro de los 18 a $60 \mathrm{~cm}(7.2$ a 24 pulg) del tronco. Ningún tratamiento de barreras redujo el número de raíces pequeñas de ambas especies más allá de $60 \mathrm{~cm}$ (24 pulg) de radio del tronco. El mantenimiento del pavimento al menos $120 \mathrm{~cm}$ (48 pulg) retirado de los árboles podría ser tan efectivo como una barrera de raíces en reducir la posibilidad de daño de raíces superficiales grandes. Un contenedor de vivero \#15 sirviendo como una barrera de raíces redujo el incremento del calibre de ambas especies, mientras que este tratamiento y el tratamiento DeepRoot ${ }^{\circledR}$ redujo el incremento en altura del Liquidambar. 